\title{
ASPEK PSIKOLOGI DAN KESEHATAN MENTAL DALAM PENDIDIKAN AQIDAH DAN IBADAH PESERTA DIDIK
}

\author{
Ahmad Syarifin \\ Dosen Pendidikan Islam Anak Usia Dini IAIN Bengkulu \\ Email: ahmadsyarifin80@gmail.com
}

\begin{abstract}
The issue of aqeedah and psychological aspects, as well as mental health in it are human needs. On the other hand, the highest needs of human beings are religion, religion is identical with belief, this belief is understood as a faith which in Islam manifests in the six pillars of faith. Psychologically humans need religion and one of the characteristics that humans are healthy is by the existence of religion. One of the mental health can be achieved through the Islamic method, through the correct implementation of the pillars of faith in daily life, so that the faith is not only imprinted in the heart, but is spoken with verbally and concretely in its behavior. The psychological aspects of worship can be seen from the nature of worship education itself. The essence is like the birth in man (psychologically) of the intensity of consciousness in thinking, then a Muslim wherever he is will feel bound to such ties of consciousness, therefore humans will act systematically based on honesty and self-confidence. In addition, Muslims who feel bound by Allah will feel the delicacy and attitude of prioritizing God as a source, with worship like this that humans will have identity (selfdevelopment), because unity has strengthened itself.
\end{abstract}

Key word: Psychology, Mental Health, Aqeedah and Worship Education, Students

Abstrak: Persoalan aqidah dan aspek-aspek psikologik, serta kesehatan mental yang ada di dalamnya merupakan kebutuhan manusia. Di sisi lainkebutuhan tertinggi manusia adalah agama, agama identik dengan keyakinan, keyakinan inilah yang dipahami sebagai keimanan yang dalam Islam berwujud pada rukun iman yang enam. Secara psikologis manusia membutuhkan agama dan salah satu ciri bahwa manusia itu sehat adalah dengan adanya agama.Adapun kesehatan mental dapat dicapai salah satunya dengan metode imaniah, melalui implementasi yang benarrukun iman tersebut dalam kehidupan sehari-hari, sehingga keimanan tidakhanya terpatri dalam hati, namun terucap dengan lisannya serta konkrit dalamlakunya.Adapun Aspek psikologis dari ibadah terlihat dari hakikat kependidikan ibadah itu sendiri. Hakikat tersebut seperti lahirnya dalamdiri manusia (secara psikologik) intensitas kesadaran dalam berfikir, kemudian seorang muslim di manapun ia berada akan merasa terikat ileh ikatan kesadaran tersebut, karenanya manusia akan bertindak dengan sistematis didasari dengan kejujuran dan kepercayaan diri. Di samping itu muslim yang merasa terikat dengan Allah akan merasakan kelezatan dan sikap mengutamakan Allah sebagai sumber, dengan ibadah yang seperti ini manusia akan memiliki jati diri (perkembangan diri), karena kesatuan akibat telah memperkokoh dirinya.

Key word: Psikologi, Kesehatan Mental, Pendidikan Aqidah dan Ibadah, Peserta Didik

\section{Pendahuluan}

Psikologi merupakan salah satu bidang keilmuan yang berusaha mengkaji persoalan kejiwaan terkait dengan gejala-gejala dan pertumbuhan dan perkembangan kejiwaan tersebut. Seperti senang ,gembira, tentram dan nyaman, resah dan gelisah. Pada bagian lainsebagai ilmu kejiwaan, psikologi juga mengkaji kesehatan mental.Dalam perkembangannya telah diyakini sebagai disiplin ilmu yang berdiri sendiri.Dalam psikologi Islam dipahami sebagai integritas yang padu dan padan serta serasidan simbang faktor-faktor kejiwaan manusia dalam rangka menyesuaikan diri dengan dirinya, adaptasi dengan manusia lain, komunikasi dengan lingkungan dan alam yang didasari oleh taqwa.

Kesehatan mental dikatakan sebagai keseimbangan antara imaniyahi, islamiyah, insaniyah, yang mencakup hubungan dengan Allah, manu- 
sia, hubungan dengan alam dan ilm.Ketika unsur-unsur tersebut tidak seimbang maka kondsi tersebut dinilai abnormal.Namun penyataan ketidaksehatan ini diiringi dengan suatu tawaran tentang bagaimana upaya mencapai kesehatan mental, salah satunya dengan terapi keagamaan (konseling agama).Metode yang digunakan dengan pendekatan pendidikan aqidah dan ibadah. Dilingkungan sekolah aqidah dan ibadah ini juga merupakan bagian dari pembelajaran yang diberikan pada peserta didik.

Pertanyaan yang akan muncul barangkali apa saja aspek psikologis dan kesehatan mental dalam pendidikan aqidah dan ibadah tersebut terutama bagi peseta didik?. ${ }^{1}$ Untuk itu kertas kerja ini berupaya untuk mengungkap persoalan-persoalan yang menyangkut pendidikan aqidah dan ibadah serta aspek psikologis dan kesehatan mental yang terdapat didalamnya.

\section{Pembahasan}

\section{Aspek-Aspek Psikologi dan Kesehatan Mental Pada Pendidikan Aqidah}

Pendidikan aqidah terkait dengankeyakinan, dalam bahasa arab secara terminologi aqidah berarti ikatan, sangkutan. Disebut demikian karena ia mengikat dan menjadi sangkutan atau gantungan segala sesuatu. Secara teknis berarti iman atau keyakinan, karnanya ditautkan dengan rukun iman yang menjadi dasar seluruh ajaran Islam, keimanan memiliki kedudukan yang sentral dan fundamental karena selain menjadi asas dalam setiap aktivitas yang menjadi titik tolak kegia-

'Term peserta didik formal adalah orang yang sedang dalam fase pertumbunhan dan perimbangan baik secara fisik maupun psikis.baca! Syakirman M Noor, Paradigma pendidikan Islam (Padang : Baitul Hikmah, $t \mathrm{t}$ ) $\mathrm{h}$. 66-67 dengan demikian dipahami sebagai kelompok manusia yang membutuhkan bimbingan dan arahan dalam menemukan jati dirinya menuju kedewasaan, ehingga mampu memanfaatkan potensi yang ada pada dirinya menuju kesejahteraan. Peserta didik bukan miniature orang dewasa akan tetapi memiliki dunia sendiri, memiliki diferensiasi periodeisasi perkembangan dan pertumbuhan. Disamping itu dipandang sebagai manusia yang memiliki kebutuhan, baik kebutuhan jasmani maupun rohani yang harus dipenuhi, peserta didik dipandang sebagai makhluk Allah yang memiliki perbedaan, sebagai manusia peserta didik juga terdiri dari dua unsur yakni jasmani dan rohani serta memiliki potensi (fitrah). Bandingkan! Samsul Nizar, Filsafat Pendidikan Islam Pendekatan Hitoris, Teoritis dan Praktis, (Jakarta : Cipuput Pers, 2002), h.48-51.

Dalam tulisan ini yang dimaksudkan bukan peserta didik dalam tatanan formal, secara umum peserta didik sebagai makhluk yang terdiri dari dimensi jasmani dan rohani, fisik dan psikis yang berbeda-beda serta memiliki potensi untuk dikembangkan artinya tidak adanya pembatas umur dan tempat serta keadaan peserta didik tersebut. tan seorang muslim. ${ }^{2}$

Guna melihat apasaja aspekpsikologi dan kesehatan mental dalam pendidikan aqidah. Maka penting kiranya diarahkan kepada cakupan pendidikan aqidah itu sendiri.secara umum pendidikan aqidah terlepas dari rukun iman. ${ }^{3}$

\section{a. Keyakinan Kepada Allah}

Hal mendasar dalam kajian adalah keyakinan bahwa Allah Maha Esa dalam sifat-sifat-Nya. Keyakinan ini berarti bahwa sifat-sifat Allah penuh kesempumaan dan keutamaan, tidak ada yang menyamainya. Dimaklumi sifat Allah sebanyak 99 yang disebut Al-Asmaul Husna bukan menunjukan bahwa sifat Allah hanya 99 melainkan sebagai gambaran bahwa sifat Allah sangat luas.

\section{b. Keyakinan Kepada Malaikat Allah}

yang diciptakan dari cahaya dan memiliki atau pembawaan melihat aspek psikologis dan kesehatan mental maka penting diarahkan pada sifat yang dimiliki malaikat tersebut :

1) Selalu taat kepada Allah

2) Membenarkan dan melaksanakan perintah Allah

3) Mengukuhkan hati orang-orang yang beriman

4) Memberi pertolongan kepada manusia

5) Membantu perkembangan manusia untuk berbuat baik

6) Mendorong manusia untuk berbuat baik

7) Mencatat perbuatan manusia

8) Melaksanakan hukuman Allah. ${ }^{4}$

Muhammad Daud Ali, Pendidikan Agama Islam, (Jakarta : Rajawal Pres, 1998) h.199 dalam kerangka fikir bangsa Indonesia. Menurut pasal 29 ayat 1 Undang-undang dasar 1945 negara berdasarkan pada Ketuhanan Yang Maha Esa. Lihat Hazairin, Tujuh Serangkai Mengenai Hukum, (Jakarta : Tintamas, 1974), 58. Sebenarnya istilah ini diciptakan dari hasil olah fikir manusia (otak) namn dipahami oleh surat Al-Baqarah : 163 :

Artinya: Dan Tuhanmu Adalah Tuhan Yang Maha Esa; Tidak Ada Tuhan Melainkan Dia Yang Maha Pemurah Lagi Maha Penyayang.Dan al-Ikhlas : 1. Katakanlah : "Dia-lah Allah yang maha Esa". Dalam islam konsep tentang ketuhanan yang maha Esa disebut tauhid. Yakni ilmu tentang kemahaesaan Tuhan. Lihat Osman Raliby Akal dan Wahyu, (Jakarta : Media Dakwah, 1980) h. 8

${ }^{3}$ Adapun ayat-ayat yang berkaitan dengan keimanan antara lain AlBaqarah : 285 :

"Rasul telah beriman kepada Al Quran yang diturunkan kepadanya dari Tuhannya, demikian pula orang-orang yang beriman. Semuanya beriman kepada Allah, malaikat-malaikat-Nya, kitab-kitab-Nya dan rasul-rasulNya. (Mereka mengatakan): "Kami tidak membeda-bedakan antara seseorangpun (dengan yang lain) dari rasul-rasul-Nya", dan mereka mengatakan: "Kami dengar dan kami taat." (Mereka berdo'a): "Ampunilah kami ya Tuhan kami dan kepada Engkaulah tempat kembali

${ }^{4}$ Percaya tentang wujud malaikat. Mereka mempunyai eksistensi mereka adalah makhluk yang diciptakan Allah mereka bukan maya bukan ilusi dan bukan pula sesuatu yang menyatu pada diri manusia. 
Sifat-sifat tersebut agaknya cukup jelas menunjukan bagaimana aspek-aspek psikologis dan kesehatan mental yang terdapat di dalamnya.Dilihat dari tugas malaikat terutama bagian tiga hingga keenam tampak langsung berhubungan dengan penumbuhan dan pengembangan kerohanian manusia. Dengan demikian manusia harus menyakini adanya kehidupan rohani yang harus dikembangkan sesuai dengan dorongan para malaikat tersebut. ${ }^{5}$

Secara psikologis manusia cenderung untuk berbuat baik. kecendrungan ini dikembangkan oleh malaikat sedangkan kecendrungan berbuat jahat dikembangkan oleh setan. Artinya manusia memiliki kecendrungan bersikap dan bertingkah laku. Sikap dan tingkah laku yang baik ini merupakan indikasi kesehatan mental. Dengan demikian sifat menumbuhkembangkan keimanan dan sikap baik manusia adalah salah dua dari aspek psikologidan kesehatan mental bagi peserta didik.

\section{c. Keyakinan pada kitab-kitab Allah}

Pembicaraan ini diarahkan pada kitab suci alQuran, kitab suci yang disampaikan kepada Nabi Muhammad SAW dengan perantara jibril. Penjelasan ini terkait dengan potensi akal yang dimiliki manusia dengan wahyu (al-Quran). Akal merupakan karunia ilahi, tujuannya agar manusia mampu melaksanakan tugas dan fungsi serta kewajibannya sebagai manusia. Dengan potensi inilah manusia memungkinkan untuk memperoleh dan mengembangkan keilmuan.

Dalam ajaran Islam akal memiliki posisi tertinggi, karena potensi inilah yang menampung aqidah, syari'ah dan akhlak.Akal mengarahkan manusia memahami sesuatu.Kesemuanya terwujud jika manusia memanfaatkan akalnya dengan baik.Akal dapat berfungsi dengan baik jika dalam kerjanya memiliki bimbingan.Pembimbing tersebut berupa wahyu, meskipun akal merupakan derajat yang paling tinggi namun wahyu tetap yang pertama sebagai takarannya, untuk itu akal perlu dikembangkan un- tuk memahami dan memanfaatkan wahyu dengan benar. ${ }^{6}$

Aspek apa yang dapat dilihat dalam kajian ini, diketahui bahwa di samping akal secara psikologi manusia dikaruniai dengan sifat sombong, pelupa, dan lalai, suka terlena dan lupa diri. Sifat-sifat ini adalah penyakit mental yang cendrung menutupi akal sehingga akal tidak dapat berfungsi sebagaimana mestinya.Dengan keyakinan kepada kitab Allah, maka akal menjadi terkontrol, sehingga mental menjadi sehat. Artinya kepercayaan kepada kitab tidak hanya memiliki aspek psikologis, namun juga membawa pada kesehatan mental.

\section{d. Keyakinan kepada nabi dan rasul}

Dalam melihat aspek psikologis dan kesehatan mental dari iman kepala rasul adalah dengan melihat sifat-sifat yang ada pada rasul itu sendiri. Kebaikan akhlak nabi ini dikenal dengan amanah, siddiq, fatanah dan tabligh. Sifat ini menjadi sumber nilai dan moral sertanorma kedua umat Islam setelah wahyu, suri tauladan yang diberikan rasul berupa perkataan. Perbuatan merupakan warisan bagi manusia dan dapat dijadikan pegangan hingga akhir zaman. $^{7}$

Meyakini nabi, konsekuensinya adalah yakin terhadap yang disampaikan oleh nabi, artinya muslim yang baik menjadikan warisan nabi sebagai pegangan dalam bicara dan bersikap dan bertindak. Secara psikologi bertindak dan bersikap merupakan fitrah manusia.Namun tindakan dan sikap yang sesuai dengan petunjuk dan yang melekat pada Rasulullah.Sikap baik dari lahir jiwa yang baik pula, artinya manusia berbuat baik menunjukan bahwa secara mental manusia tersebut stabil dan sehat.

\section{e. Keyakinan terhadap hari Kiamat}

Keyakinan kepada hari akhir medorong manusia menyesuaikan diri dengan kerangka nilai abadi yang di tetapkan Allah.Keyakinan kepada nilai abadi yang ditetapkan Allah.Keyakinan kepada hari akhir ini pula mendorong manusia mengembangkan kepribadiannya secara sehat dan mantap. ${ }^{8}$
${ }^{5}$ Percaya bahwa mereka adalah hamba-hamba Allah yang taat yang diberikan tugas tertentu oleh-Nya, namun bagaimana mereka melakukan tugasnya tidaklah menjadi kewajiban mempercayainya. Baca! M. Quraish, Yang Tersembunyi Jin Iblis Setan Dan Malaikat Dalam Al-Quran As Sunnah Serta Wacana Pemikiran Ulama Masa Lalu Dan Masa Kini,( Jakarta : Lentera Hati, 1999) h. $246-252$

\footnotetext{
${ }^{6}$ Muhammad Daud Ali, Op. cit, h.219

'Tbid, h. 225

${ }^{8}$ Altaf Gaufar, Tantangan Islam (Bandung : Pustaka, 1983) h,14-15
} 


\section{f. Keyakinan kepada Qadha dan Qadar}

Prinsip yang dapat diambil dari kepada Qada dan Qadar ini adalah bahwa manusia bebas memiliki pertanggungjawaban perbuatan yang akan dilakukannya. Ia bebas pula menentukan kepercayaan yang dianutnya dan dia akan memperoleh sesuatu baik hukuman maupun pahala sesuai dengan pilihannya itu. Allah hanya menunjukan jalan, manusia bebas memilih menuruti atau meninggalkannya. Karenanya manusia harus berupaya untuk menyelamatkan diri, penyelamatan ini hanya didapat dari beriman dan beramal shaleh.

Memahami takdir hendaknya dengan ikhtiar. Karena takdir berkaitan erat dengan ikhtiar manusia.Karena itu usaha harus seoptimal dan semaksimal mungkin diiringi dengan tawakal.Inilah pilar takdir sebenarnya, yang berlangsung melalui proses ikhtiar dan doa serta usaha manusia.

Demikianlah persoalan aqidah dan aspek-aspek psikologik, serta kesehatan mental yang ada di dalamnya.Dengan demikian dapat dianalisa berdasarkan teori kebutuhan manusia. ${ }^{10}$ Kebutuhan tertinggi manusia adalah agama, agama identik dengan keyakinan, keyakinan inlah yang dipahami sebagai keimanan yang dalam Islam berwujud pada rukun iman yang enam.WHO merumuskan bahwa salah satu dimensi kesehatan adalah manusia beragama sesuai dengan fitrahnya.Artinya secara psikologis manusia membutuhkan agama dan salah satu ciri bahwa manusia itu sehat adalah dengan adanya agama.Penting juga dikemukakan bahwa kesehatan mental dapat dicapai salah satunya dengan metode imaniah, melalui implementasi yang benarrukun iman tersebut dalam kehidupan sehari-hari, sehingga keimanan tidakhanya terpatri dalam hati, namun terucap dengan lisannya serta konkrit dalamlakunya.

\section{Aspek-Aspek Psikologik DanKesehatan Men- tal Pada Pendidikan Ibadah}

Dunia modern telah mengakui bahwa manusia tidak dapatdipisahkan antara tubuh, akal dan spiritual, karena dalam setiap sistem berfikirmanusia memerlukan sarana perealisasian. Perwujudan ini

${ }^{9}$ Muhammad Daud Ali, Op. cit, h.229-231

${ }^{10}$ Seorang ahli psikologi Abraham Maslow beraliran Humanistik yang terkenal dengan teori motivasinya mengemukakan lima kebutuhan manusia, yakni The Phyciological nedds, The esteem needs and The needs for self actualization. hanya nampakjika disertai dengan penyemangat, ikhtiar dan gerakan tubuh yang sistematis.Dengan demikian manusia tersebut dapat dikatakan selaras dalam hal karakter psikologis, daya intelektual dan kemampuan fisik.

Islam dengan keuniversalannya jauh sebelum itu telah memiliki suatu sistem telah memiliki suatu sistem tersendiri-sistem Islam tidak dapat disejajarkan dengan sistem yang lain-yanglebih sempurna dan edukatif. Kesempurnaan ini terlihat jelas ketika manusia berbuat baik manusia dinilai sebagai ibadah dan dipandang sebagai latihan spiritual, diikat oleh makna yang hakiki dan bersumber dari fitrah manusia. Ibadah dilaksanakan sebagai pengaturan pola hidup melalui pelaksanaan shalat, pengaturan pola makan dan minum melalui puasa, pengaturan pola sosial dan perekonomian melalui zakat, pengaturan pola integritas umat dan persaudaraan melalui haji. ${ }^{11}$

Uraian diatas menunjukan bahwa dalam aktifitas ibadah manusia telah menyatukan manusia pada pada satu tujuan, berupa penghambaan kepada Allah. Dengan demikian dalam setiap tarikan nafas, ayunan kaki dan derap langkah manusia diisi dengan ibadah sebagai penjinak nafsu dalam diri manusia. Bangun ketika fajar dan tidur setelah malam semata-mata berdzikir kepada Allah. Makan dan minum yang halal, mengeluarkan sebagian rezeki untuk kesejahteraan. Serta mengawali segala kegiatan dengan doa dan mengingat-Nya yang biasa disebut ibadah.

Melalui pendidikan ibadah banyak hal yang dapat diperoleh oleh seorang muslim yang kepentingannya bukan hanya mencangkup individual, melainkan bersifat luas dan universal. Disamping itu pendidikan ibadah memiliki aspek-aspek psikologik dan kesehatan mental. Dilihat dari segi hikmah kependidikan, ${ }^{12}$ dalam ibadah maka dapat disarikan bahwa dalam konsep islam melalui ibadah menusia diajarkan untuk memiliki intensitas kesadaran berfikir. Namun pelajaran atau hikmah ini dapat terwujud ketika ibadah yang dilakukan benar-benar memenuhi persyaratan yang disyari-

\footnotetext{
${ }^{11}$ Abdurrahman an Nahlawi,Ushul Tarbyah Islamiyah wa Asalibha fl Baiti wal Madrasati wa Mujtama'; Terjm. Shihabuddin (Jakarta: Gema Insani Press, 1995) h. 62

${ }^{12}$ Ibid., h. $62-65$
} 
atkan. Pendidikan ibadah akan menuntutmanusia memiliki keterkaitan, kesadaran diri, sistematis, kuat, serta didasarkan pada kesadaran, karena pada dasarnya tidak ada kesadaran yang lahir selain dari Allah.

Sejalan dengan kajian ini, maka akan diungkap apa saja aspek psikologik dan kesahatan metal dalam pendidikan puasa, shalat, zakat dan haji.

\section{a. Aspek psikologis dan kesehatan mental dalam puasa}

Selain sebagai kewajiban yang dibebankan Allah kepada manusia-dalamhal ini orang-orang yang beriman - puasa merupakan tindak ibadah, wujud pengabdian kepada Allah yang sesungguhnya sebagai pekerjaan rohani, sekalipun di dalamnya melibatkan aktifitas jasmani, kejiwaan dan sosial.

Dilihat dari hikmahnya puasa memiliki hikmah yang tidak terhitung, terutama hikmah dari sisi rohani. Salah satu hikmah puasa adalah sebagai benteng dari api neraka, dapat menghapuskan dosa fitnah, dan dapat mengantarkan kita ke gerbang kerajaan ilahi. ${ }^{13}$

Yang merupakan hikmah -hikmah rohaniah yang tidak diketahui prosesnya. Ini tidak menghenrankan, karena masalah tuh adalah urusan Allah, dan puasa adalah ibadah untuk Allah, yang mendapat ganjaran langsung dari Allah.

Dilihat dari sisi fisik puasa memberikan pengaruh dan faedah bagi kesehatan tubuh dan kematangan kejiwaan serta mampu meningkatkan keakraban sosial. Namun demikian faedah tersebut tidak mampu meningkatkan posisi puasa sebagai tindak ibadah yang memiliki hikmah secara rohaniah. Kenapa dimikian karena kesehatan fisik dan kejiwaan dan kepekaan sosial dapat dicapai dengan cara yang lain dan tidak melalui puasa. Hal yang mendasar puasa memberikan latihan pembersihan diri dan peningkatan ruh. Pembersihan diri dari penyakitpenyakit mental dan kejiwaan. Dalam kaitan inilah

${ }^{13}$ Hadis Nabi menyebutkan bahwa "puasa itu adalah perisai dan benteng yang kokoh terhadap api neraka" (HR. Ahmad dan Hambal) pada hadishadis lain hal senada juga dapat dipahami sesungguhnya di dalam syurga ada sebuah pintu yang disebut ar Rayyan. Pada hari kiamat orang-orang yang berpuasa masuk ke syurga melalui pintu itu. Tak seorang pun masuk dari pintu itu selain mereka. Mereka dipanggil "mana orang yang berpuasa?" lalu mereka berdiri tak seorangpun yang dapat msauk melalui pintu itu selain mereka. Setelah mereka masuk pintu dikunci dan tak seorangpun yang dapat masuk lagi" akan dikemukakan aspek psikologis dan kesehatan mental dalam ibadah puasa.

Pembelajaran ibadah (puasa) jika dilaksanakan dengan penuh ketaatan serta kekihklasan maka akan ditemukan manfaat psikologisnya di antaranya dapat didasarkan sebagai berikut:

1) Mencegah diri dari sikap serba mementingkan kenikmatan semata dan menggantikannya dengan keridhaan Allah sebagai nilai tertinggi

2) Pengendaliab dan menahan serta mencegah dorongan untuk berbuat tercela yang tidak sesuai dengan tuntutan kejiwaan

3) Upaya mengembangkan diri secara menyeluruh baik secara fisik, mental dan sosial maupunspiritual

4) Proses pengembangan potensi diri melalui akitualisasi

Dapat ditegaskan bahwa secara psikologis puasa memberikan dampak yang signifikan pada kejiwaan manusia. Pertanyaannya adalah puasa yang bagaimana yang mampu atau dinilai memberikan pengaruh pada kejiwaan manusia.Pertanyaan ini dapat dijawab dengan rumus ilmu pasti. Sebagai berikut $:^{14}$

- $\quad+\mathrm{x}+=+$

- $\quad+\mathrm{x}-=-$

- $-\mathrm{x}+=-$

$-\quad-\mathrm{x}-=+$

Yang dimaksud rumus di atas adalah :

1) Puasa (+) disertai dengan hati ikhlas/bersih (+), hasilnya baik $(+)$

2) Puasa $(+)$ didasari hati yang tidak ikhlas/tidak bersih (-), hasilnya tidak bersih/tidak mendapat pelajaran yang haji $(+)$

3) Bila tidak mau menjalankan ibadah puasa (-), sekalipun tidak mau menjalankan ibadah upasa (-), sekalipun orangnya kelihatan baik $(+)$ maka ganjaran puasa tidak akan diperolahnya.

4) Orang jahat (-) yang senang sekali mempelajari ilmu-ilmu hitam hasilnya positively (-) keji.

Dapat ditegaskan bahwa pendidikan ibadah puasa memiliki aspek psikologis seperti pengem-

${ }^{14}$ Hanna Djumhana Bastaman, Intergrasi Psikologi dengan Islam Menuju Psikologi Islam, Jakarta Pustaka Pekajar, 1997), h. 187 
bangan sikap sabar. Bertindak dan bertutur seimbang serta memiliki pola sikap yang mampu menghargai orang lain, teratur serta bijaksana dan empati, komitmen dan disiplin. Di samping itu juga membawa pengaruh kepada kesehatan mental, sebab puasa mampu membawa manusia kepada suatu kondisi kejiwaan yang tenang, nyaman dan tentram. Ketentraman dan ketenangan jiwa inilah yang menunjukkan seseorang sehat secara mental.

\section{b. Aspek psikologik dan kesehatan mental da- lam shalat}

Shalat merupakan wujud dari pengakuan manusia sebagai orang Islam, shalat tidak hanya dipandang sebagai suatu kewajiban dan rutinitas seorang muslim namun juga sebagai kebutuhan jiwa, panggilan nurani. Pembinaan ibadah shalat diperintahkan rasul ketika anak sudah mulai menginjak usia tujuh tahun dan jika telah sepuluh tahun belum juga melaksanakan shalat maka orang tua diperbolehkan berindak tegas dengan memikilnya.

Hal ini menunjukkan bahwa secara psikologis sesuai dengan pertumbuhan dan perkembangan kejiwaan anak, pada usia tujuh tahun anak telah mampu membedakan antara baik dan yang buruk sehingga kecenderungan kejiwaan pada yang baik dipandang jiwa kebergamanya belum matang, sehingga shalat hanya sebagai rutinitas dan bukan kebutuhan jiwa. Dengan demikian dapat dipahami bahwa jiwa keberagamaan anak secara psikologis berkembang ketika anak telah mencapai usia akhil baligh.

Dari sudut kesehatan mental, dapat dilihat dari inti atau hakikat shalat itu sendiri. Hakikat shalat adalah zikir dan do'a, dalam Islam zikir dan do'a memiliki kekuatan yang luar biasa, pektrum shalat pada kondisi kejiwaan manusia sangat signifikan. Dalam hal ini agaknya dapat dilihat pada pengaruh yang ditumbulkan oleh orang yang melakukan dan yang tidak. Orang yang shalat cenderung memiliki ketenangan seperti ketenangannya ketika shalat, sedangkan orang yang tidak shalat cebnderung gusar seperti gusamya ketika berbicara.

Kekuatan zikir dan do'a inilah yang membawa mental manusia menajdi lebih sehat dan bersih, sehatnya mental ini diperoleh melalui dialog suci dengan Allah pada tiap paruh waktu dan keadaan yang telah ditentukan. Komunikator yang lancar akan membuahkan persoalan orang yang bermasalah ketika orang tersebut mengadukannya, demikian juga sebaliknya.

Hal mendasar lainnya yang dapat disoroti, bahwa shalat memupuk rasa persamaan hak dan derajat, karena di mata Allah manusia memiliki kedudukan yang sama dan yang membedakannya adalah taqwanya, wujud dari ketaqwaan itu salah satunya dilihat dari shalat atau tidaknya seseorang. Disamping itu dilihat dari prosesi pelaksanaan shalat manusia tidka ditentukan posisinya di depan atau di belajang, dengan satu pimpinan (imam).

\section{c. Aspek psikologik pada zakat}

Dalam tatanan kehidupan manusia diatur sedemikian rupa, persoalan ekonomi diformat dengan bentuk zakat, sebagai ibadah zakat merupakan kewajiban, namun pada sisi lain zakat mengandung aspek psikologik dan memberikan pengaruh pada kesehatan mental. Pada pendidikan zakat manusia diajarkan tentang penyucian harta dan diri. Menyerahkan harta bukan dipandang sebagai suatu pengurangan melainkan sebagai penyucian harta itu sendiri. Penyucian diri dapat dipahami sebagai penyucian dari sifat dengki, kikir dan pelit serta merasa berkuasa terhadap harta tersebut.

Dengan zakat sekaligus memberikan sifat-sifat tersebut (sifat-sifat berupa penyakit mental) dari dalam diri manusia dan dengan sendirinya manusia akan terhindar dari penyakit mental. Sifat buruk tersebut berganti dengan sifat saling menghargai, empati, saling memiliki dan menghormati serta persaudaraan yang tinggi. Artinya secara psikologis zakat menajdi rasa antara mutaqqi dan mustahid.

\section{d. Aspek psikologis dan kesehatan mental iba- dah haji}

Haji merupakan salah satu ibadah yang membawa manusia pada satu keadaan kebersamaan dan persamaan, bagaimana kedudukan manusia dihadapan Allah dengan demikian akan lahir perasaan menghargai orang lain. Memandang orang lain sama dengan dirinya dan dapat menerima keberadaan diri dan orang orang lain disekitamya.

Uraian di muka memberikan informasi bahwa dalam setiap pembelajaran adalah menyangkut rukun islam yang lima memiliki aspek psikologik masing-masing serta mengandung aspek kesehatan mental atau dengan kata lain melalui ibadah dapat mencapai kesehatan mental. Aspek psikolo- 
7 管

7 NUANSA Vol. XI, No. 1, Juni 2018
Ah m ad Syarifin | Aspek Psikologi dan Kesehatan Mental 7

lam sedangkan pendidikan ibadah terkait dengan rukun islam

gis dari ibadah terlihat haklikat kependidikan ibadah itu sendiri. ${ }^{15}$ Hakikat tersebut seperti lahirnya dalamdiri manusia (secara psikologik) intensitas kesadaran dalam berfikir, kemudian seorang muslim di manapun ia berada akan merasa terikat ileh ikatan kesadaran tersebut, karenanya manusia akan bertindak dengan sistematis didasari dengan kejujuran dan kepercayaan diri. Di samping itu muslim yang merasa terikat dengan Allah akan merasakan kelezatan dan sikap mengutamakan Allah sebagai sumber, dengan ibadah yang seperti ini manusia akan memiliki jati diri (perkembangan diri), karena kesatuan akibat telah memperkokoh dirinya.

Pendidikan ibadah juga membawa pada suatu keadaan yang bisa bangga dengan kemuliaan Allah. Dengan mengakamya rasa ini dalam jiwa manusia, maka setiap insan akan sistiqamah dan senantiasa berada dalam batas-batas yang wajar, hingga simalah kezhaliman, kecongkakan, eksploitas kehinaan, perbudakan atau rasialisasi.

Dari sudut sosial, secara spikologis manusia adalah makhluk yang tidak mampu hidup sendiri, secara umum ibadah akan melahuirkan sikap kebersamaan yang akan menunjang akan kebersamaan tadi, dengan demikian manusia terdorong untuk saling mengenal, saling menasehati. Kebersamaan inilah nantinya yang akan melahirkan persamaan hak, menghargai karakter diri, ketrampilan, kemampuan dan ketakwaan serta kselahe diri.

Pendidikan ibadah akan membawa manusia pada sikap optimis memperbaruhi jiwa, ekpresi tabat. Dalam kajian psikologi dan kedoteran serta kesehatan mental, bersepakat bahwa taubat dapat menyembuhkan berbagai krisis dan penyakit biologis, yakni dengan mengembalikan manusia pada adaptasi dengan diri, prinsip idealis dan toleransi.

\section{Kesimpulan}

Sejalan dengan permasalahan yang diketengahkan dan melihat uraian di atas maka dapat disimpulkan sebagai berikut :

1. Pendidikan aqidah dan ibadah merupakan hal mendasar dalam agama Islam, pendidikan aqidah terkait dengan pembelajaran tentang enam rukun iman ditambah syahadat dalam rukun is-
2. Aspek psikologi dan kesehatan mental dalam pendidikan aqidah dilihat dari kebutuhan manusia akan agama dan dengan metode imaniah manusia dapat mencapai kesehatan mental

3. Aspek psikologis dan kesehatan mental dalam pendidikan ibadah dilihat dari kebutuhan manusia akan ibadah, ibadah dapat membawa manusia kepada kesehatan mental. Artinya dengan ibadah bikin hidup lebih hidup.

\section{Daftar Pustaka}

Abdul Hafidz, Muhammad Nur. Manhaj Al-Tarbiyah Al-Nahawiyah Li Al-Thifi Terj. Kuswandi, Bandung : Mizan 1997.

Ali Muhammad Daud. Pendidikan Agama Islam. Jakarta : Rajawali Pers. 1998

Bastaman, Hanna Djumhana. Integrasi Psikologi Dengan Islam Menuju Psikologi Islami, Jakarta : Pustaka Pelajar, 1997.

Gauhar, Altaf. Tantangan Islam, Bandung : Pustaka, 1983

Maslow, Abraham. Motivation And Personality, Sansfransisco: Haper And Row Publisher, 1970

Noor, Syakirman M. Paradigma Pendidikan Islam, Padang : Baitul Hikmah, Tt

Nizar, Samsul. Filsafat Pendidikan Islam Pendekatan Historis, Teoritis Dan Praktis, Jakarta : Ciputat Pers, 2002.

An-Nahlawi, Abdurahman, Ushulut Tarbiyah Islamiyah Wa Asalibiha Fil Baiti Wal Madrasati Wa Mujtama, Jakarta : Gema Insani Perss, 1995

Raliby, Osman. Akal Dan Wahyu, Jakarta : Gema Insani Press, 1995

Shihab, M. Quraish, Yang Tersembunyi Jin Iblis Setan Dan Malaikat Dalam Al-Quran As Sunnah Serta Wacana Pemikiran Ulama Masa Lalu Dan Masa Kini, Jakarta : Lentera Hati, 1999 
忞

8 NUANSA Vol. XI, No. 1, Juni 2018
急 8 